SHORT COMMUNICATION

\title{
First record of Aedes (Stegomyia) albopictus in the state of Amapá, northern Brazil
}

\author{
Jose Ferreira SARAIVA ${ }^{1 *}$, Ahana MAITRA ${ }^{1}$, Allan Kardec Ribeiro GALARDO ${ }^{2}$, Vera Margarete SCARPASSA ${ }^{1}$ \\ Instituto Nacional de Pesquisas da Amazônia - INPA, Coordenação de Biodiversidade - COBIO, Laboratório de Genética de Populações e Evolução de Mosquitos \\ Vetores de Dengue e Malária, Avenida André Araújo, 2936, Petrópolis, 69067-375 Manaus, Amazonas, Brazil \\ 2 Instituto de Pesquisas Científicas e Tecnológicas do Estado do Amapá - IEPA, Laboratório de Entomologia Médica, Núcleo de Biodiversidade, Rodovia Juscelino \\ Kubitschek, Km-10, Fazendinha, 68903-419 Macapá, Amapá, Brazil \\ * Corresponding author: jfsento@gmail.com
}

\section{ABSTRACT}

We report the first record of Aedes albopictus (Diptera: Culicidae) in the state of Amapá, northern Brazil. Two female specimens were collected from a Shannon trap in the locality of Ilha de Santana, municipality of Santana, Amapá. The occurrence of the species was confirmed with the installation of ten ovitraps. Aedes albopictus is a species of epidemiological importance for the transmission of arboviruses. Amapá was one of two Brazilian states without any record of this species.

KEYWORDS: arboviruses; dengue; yellow fever; mosquitoes

\section{Primeiro registro de Aedes (Stegomyia) albopictus no Estado do Amapá, Brasil}

\section{RESUMO}

Relatamos o primeiro registro de Aedes albopictus (Diptera: Culicidae) no Estado do Amapá, no norte do Brasil. Dois espécimes foram coletados em uma armadilha de Shannon na localidade de "Ilha de Santana", município de Santana, no Amapá. O registro foi confirmado com a instalação de dez ovitrampas. Aedes albopictus é uma espécie com importância epidemiológica na transmissão de arboviroses. O Amapá era um de dois estados brasileiros sem registro dessa espécie.

PALAVRAS-CHAVE: arboviroses; dengue; febre amarela; mosquitos

Aedes (Stegomyia) albopictus Skuse (Diptera: Culicidae) is an invasive mosquito, native to the forests of southeast Asia, where it is an important vector of dengue virus (Gratz 2004), and other 22 arboviruses, including the Zika and Chikungunya viruses (Paupy et al. 2009). The species was so successful in its geographic expansion that today it is found in more than 28 countries beyond its original range (Benedict et al. 2007). Tropical countries were most affected by this expansion, mainly due to the adequate temperature and humidity conditions that allowed the species to adapt into the new environments (Alto and Juliano 2001; Benedict et al. 2007).

In Brazil, Aedes albopictus was first recorded in 1986, in the southeastern state of Rio de Janeiro (Forattini 1986). Within a few years, the mosquito was reported from the whole southeastern region of the country (Brito et al. 1986; Consoli and Oliveira 1994), and had also expanded to the south (Sant'Ana 1996), western-central (Santos and Nascimento
1998) and northeastern regions of Brazil (Martins et al. 2006; Santana et al. 2014). In northern Brazil, the first record of the mosquito was in 2002, in the state of Pará (Segura et al. 2003), and it had not yet been recorded in the states of Amapá and Acre (Carvalho et al. 2014). This is the first report of $A e$. albopictus in the state of Amapá.

Amapá is located in the extreme north of Brazil, sharing borders with French Guiana and Suriname to the north, the Brazilian state of Pará to the south, and the Atlantic Ocean in the east (Figure 1a). The municipality of Santana is located in the southeast of Amapá, on the left margin of the Amazonas river, at the entrance of its estuary into the Atlantic Ocean (Figure 1b). It is the second most populous and one of the most economically important municipalities in the state, and the presence of a large port of strategic importance, due to its proximity to commercial routes in the North Atlantic (IBGE 2017). 


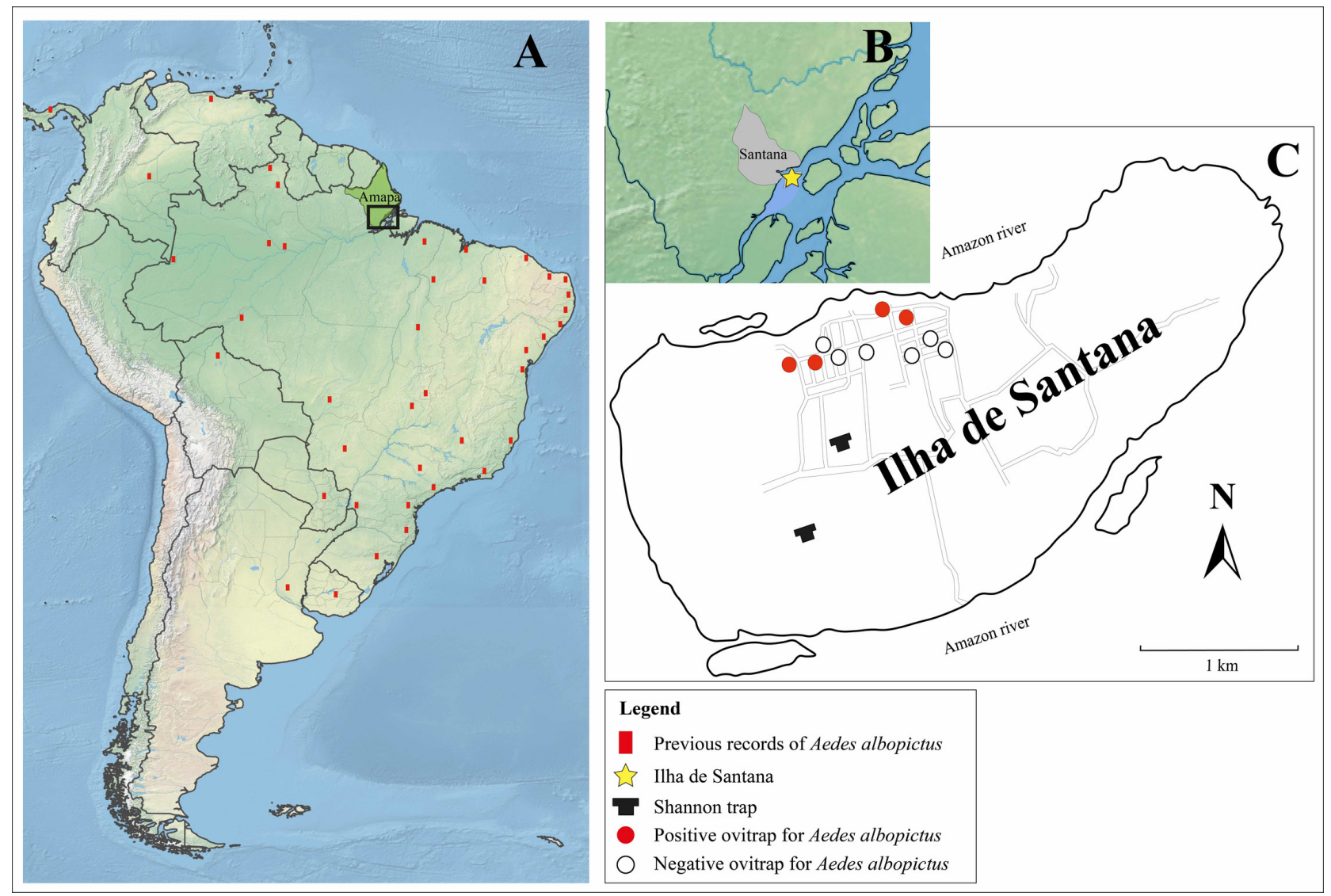

Figure 1. Location of the first record of Aedes albopictus in the state of Amapá, northern Brazil. A) Geographical distribution of Aedes albopictus in South America (red rectangles), and the new record of Aedes albopictus in the state of Amapá (rectangle); B) State of Amapá, detail of Santana municipality and Ilha de Santana (yellow star); C) Ilha de Santana, showing the urbanized perimeter, and the location of the two Shannon traps (black symbol), 10 ovitraps (circles). Red circles indicate positive, and white circles indicate negative traps for Aedes albopictus. This figure is in color for the electronic version.

Ilha de Santana (or Santana Island) is an island on the Amazonas river, located opposite to the city of Santana, at 800 $\mathrm{m}$ from the margin (Figure $1 \mathrm{~b}$ ), and is currently a part of the municipality of Santana. The island has a total area of 2,005 ha, and is covered by five types of vegetation [semi-deciduous tropical rainforest, seasonal flood-plain tropical rainforest, mangrove forest, cerrado (Brazilian savanna) and Junco forest (Valente et al. 1998)]. The climate is predominantly of the Amw type, according to the Köppen classification, with a mean annual temperature range of $23-32{ }^{\circ} \mathrm{C}$, and annual rainfall varying from 60 to $1,900 \mathrm{~mm}$ (Valente et al. 1998). The island is sparsely populated, with inhabitants living mainly of small scale agriculture, livestock farming and açaí (Euterpe oleracea Mart) extraction. The largest village is located on the northern bank of the island (Figure 1c), and is surrounded by highly anthropized secondary forest vegetation. The water and sewage treatment system is inadequate on the entire island. The record of Ae. albopictus occurred during a survey of mosquitoes on Ilha de Santana for a taxonomic study of the genus Anopheles Meigen (subgenus Nyssorhynchus). On $4^{\text {th }}$ and $5^{\text {th }}$ of May, 2018, a Two Shannon light traps (Shannon
1939) were installed in secondary forest (0.4'37.27"S; $51^{\circ} 10^{\prime} 55.12^{\prime \prime} \mathrm{W}$ and $04^{\prime} 47.64^{\prime \prime S}$; 51 $\left.1^{\circ} 11^{\prime} 9,43^{\prime \prime} \mathrm{W}\right)$, in the outskirts of the main village (Figure 1c). The traps were active on 4 and 5 May 2018, from 6:00 to 9:00 pm, and were revised every 30 minutes. Captured mosquitoes were collected by hand aspirator, placed in paraffin cups and transported to the Laboratory of Medical Entomology of the Instituto de Pesquisas Científicas e Tecnológicas do Estado do Amapá - IEPA, where they were identified according to the entomological keys of Consoli and Lourenço-de-Oliveira (1994) and Forattini (2002).

The first record of Ae. albopictus was a single female (Figure 2) captured on March 4, 2018, in the interval from 6:30 to 7:00 $\mathrm{pm}$ in the Shannon trap located at $50 \mathrm{~m}$ from the forest edge and $500 \mathrm{~m}$ from the urban perimeter of the main village (Figure 1c). Another adult female of Ae. albopictus was collected on the following day, in the second Shannon trap, located at approximately $540 \mathrm{~m}$ from the other trap (Figure 1c). To confirm the occurrence of Ae. albopictus, ten ovitraps were installed along the urbanized perimeter of the main village (Figure 1c). As the active dispersal of Ae. albopictus is 

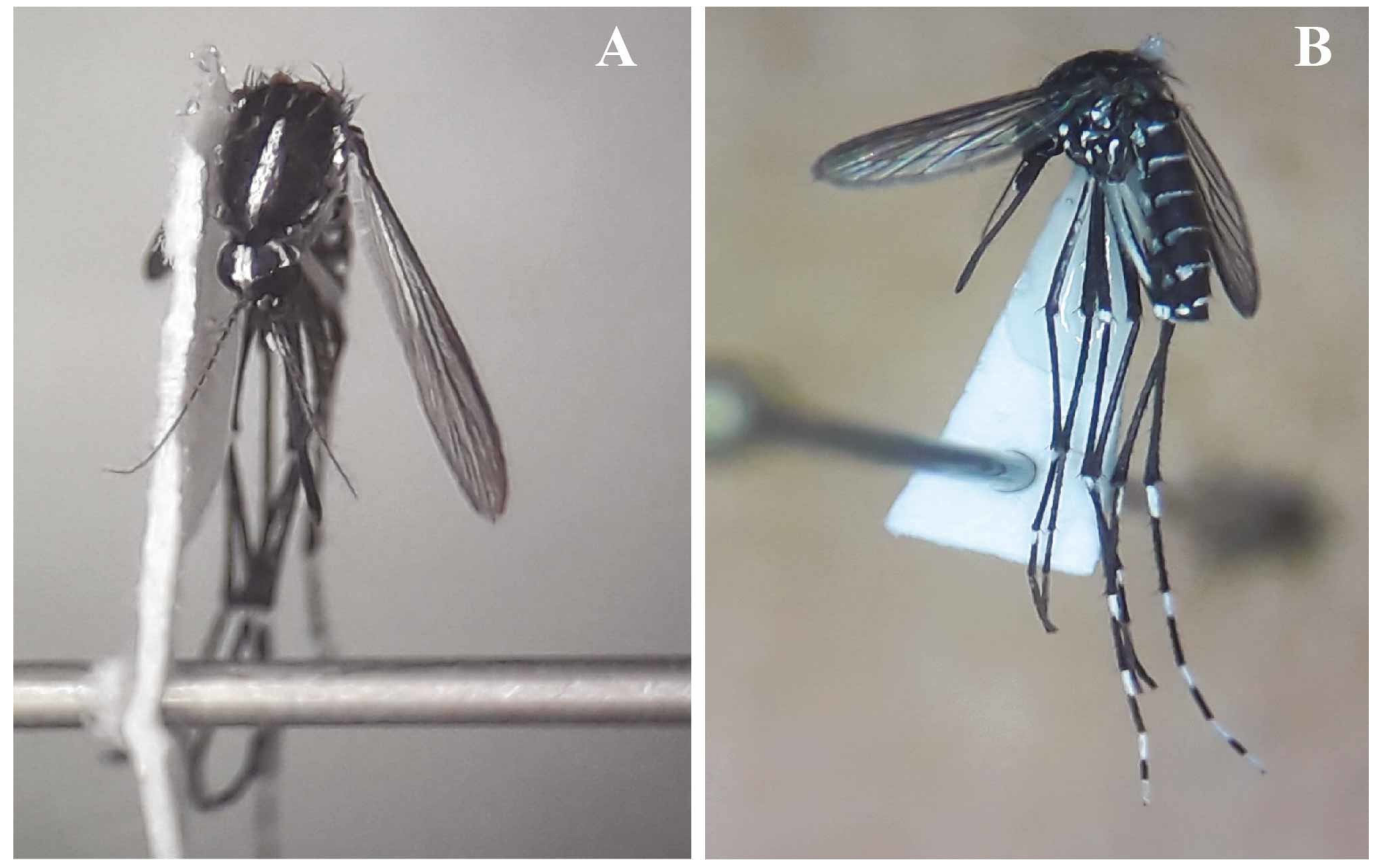

Figure 2. First specimen of Aedes albopictus (adult female) collected on llha de Santana, the state of Amapá, northern Brazil (voucher IEPA \#11072). A) Dorsal view; B) Lateral view. This figure is in color for the electronic version.

of approximately $200-500 \mathrm{~m}$ (Liew and Curtis 2004), all the ovitraps were installed at a distance of $200 \mathrm{~m}$ from each other. The traps were active for four days, from 14 to 18 May 2018, to avoid the emergence of larva in the field. Four of the ten ovitraps were positive for Ae. albopictus (Figure 1c), with a total of 62 Ae. albopictus specimens $[25$ males and 37 females]. The two females Ae. albopictus collected in the Shannon traps were deposited in the entomological collection of IEPA (vouchers \# 11072 and 11073).

Aedes albopictus possibly arrived in southern Amapá through the port of Santana and settled in Ilha de Santana due to its proximity to the port and also because, unlike Aedes aegypti, this species prefers rural, forest and periurban environments (Forattini 2002). The extent of its dispersion in Amapá is unknown. In the north, Ae. albopictus has not yet been registered in French Guiana (Talaga et al. 2015), Suriname or Guyana (WRBU 2018).

In tropical countries, Ae. albopictus was reported to transmit dengue, yellow fever and equine encephalitis viruses (Gratz 2004). Another concern is that this mosquito may act as an infestation bridge between rural and urban environments (Santos 2003). Although in Brazil Ae. albopictus is not yet classified as a natural vector of dengue and yellow fever, laboratory tests have demonstrated the successful transmission of the dengue and chikungunya viruses by this species (Castro et al. 2004; Vega-Rúa et al. 2014). Our record reinforces the necessity of entomological surveillance of this mosquito vector in the Amazon region, where 34 arbovirus serotypes of medical importance are in circulation (Travassos da Rosa et al. 2000).

\section{ACKNOWLEDGMENTS}

We are grateful to the Instituto de Pesquisas Científicas e Tecnológicas do Estado do Amapá (IEPA) for all the support provided, and to Mr. Anibrata Pal for the suggestions and corrections of the final version of the text.

\section{REFERENCES}

Alto, B.W.; Juliano, S.A. 2001. Precipitation and temperature effects on populations of Aedes albopictus (Diptera: Culicidae): implications for range expansion. Journal of Medical Entomology, 38: 646-656.

Benedict, M.Q.; Levine, R.S.; Hawley, W.A.; Lounibos, L.P. 2007. Spread of the tiger: global risk of invasion by the mosquito Aedes albopictus. Vector-borne and Zoonotic Diseases, 7: 76-85.

Brito, M.; Marques, G.R.A.M.; Marques, C.C.A.; Tubaki, R.M. 1986. Primeiro encontro de Aedes (Stegomyia) albopictus (Skuse) no Estado de São Paulo (Brasil). Revista de Saúde Pública, 20: 489.

Carvalho, R.G.; Lourenço-de-Oliveira, R.; Braga, I.A. 2014. Updating the geographical distribution and frequency of Aedes albopictus in Brazil with remarks regarding its range in the Americas. Memórias do Instituto Oswaldo Cruz, 109: 787-796.

Castro, M.G.; Nogueira, R.M.R.; Schatzmayr, H.G.; Miagostovich, M.P.; Lourenço-de-Oliveira, R. 2004. Dengue virus detection by using reverse transcription-polymerase chain reaction in saliva and progeny of experimentally infected Aedes albopictus from Brazil. Memórias do Instituto Oswaldo Cruz, 99: 809-814. 
Consoli, R.A.G.B.; Lourenço-de-Oliveira, R. 1994. Principais Mosquitos de Importância Sanitária no Brasil. Ed. Fiocruz, Rio de Janeiro, 228p.

Forattini, O.P. 2002. Culicidologia Médica, Identificação, Biologia, Epidemiologia. v.2. Editora USP, São Paulo, 860p.

Forattini, O.P. 1986. Identificaçáo de Aedes (Stegomyia) albopictus (Skuse) no Brasil. Revista de Saúde Pública, 20: 244-245.

Gratz, N.G. 2004. Critical review of the vector status of Aedes albopictus. Medical and Veterinary Entomology, 18: 215-227.

IBGE. 2017. Cidades. (http://cidades.ibge.gov.br/). Accessed on 01 Oct 2018.

Liew, C.; Curtis, C.F. 2004. Horizontal and vertical dispersal of dengue vector mosquitoes, Aedes aegypti and Aedes albopictus, in Singapore. Medical and Veterinary Entomology, 18: 351-360.

Martins, V.E.P.; Martins, M.G.; Araújo, J.M.P.; Silva, L.O.R.; Monteiro, H.A.O.; Castro, F.C.; et al. 2006. Primeiro registro de Aedes (Stegomyia) albopictus no Estado do Ceará, Brasil. Revista de Saúde Pública, 40: 737-739.

Sant'Ana, A.L. 1996. Primeiro encontro de Aedes (Stegomyia) albopictus (Skuse) no estado do Paraná, Brasil. Revista de Saúde Pública, 30: 392-393.

Santana, A.C.S.; Araújo, C.Z.D.; Novaes, J.P.; Santos, M.G.M.; Santana, W.S. 2014. Primeira ocorrência de Aedes (Stegomyia) albopictus (Skuse) no Estado de Sergipe. EntomoBrasilis, 7: 227-229.

Santos, R.L.C. 2003. Atualização da distribuição de Aedes albopictus no Brasil (1997-2002). Revista de Saúde Pública, 37: 1-4.

Santos, S.O.; Nascimento, J.C. 1998. Primeiro registro da presença do Aedes (Stegomyia) albopictus (Skuse) em Mato Grosso do Sul, Brasil. Revista de Saúde Pública, 32: 486.
Segura, M.N.O.; Monteiro, H.A.O.; Lopes, E.S.; Silva, O.V.; Castro, F.C.; Vasconcelos, P.F. 2003. Encontro de Aedes albopictus no Estado do Pará, Brasil. Revista de Saúde Pública, 37: 388-389.

Shannon, R. 1939. Methods for collecting and feeding mosquitos in jungle yellow fever studies. The American Journal of Tropical Medicine and Hygiene, 1: 131-140.

Paupy, C.; Delatte, H.; Bagny, L.; Corbel, V.; Fontenille, D. 2009. Aedes albopictus, an arbovirus vector: from the darkness to the light. Microbes and Infection, 11: 1177-1185.

Talaga, S.; Dejean, A.; Carinci, R.; Gaborit, P.; Dusfour, I.; Girod, R. 2015. Updated checklist of the mosquitoes (Diptera: Culicidae) of French Guiana. Journal of Medical Entomology, 52: 770-782.

Travassos da Rosa, A.P.A.; Pinheiro, F.P.; Travassos da Rosa, E.S.; Rodrigues, S.G.; Travassos da Rosa, J.F.S.; Vasconcelos, P.F.C. 2000. Arboviroses. In: Tonelli, E.; Freire, L.M.S. Doenças Infecciosas na Infância e Adolescência. 2nd ed. MEDSI, Rio de Janeiro, p.986-1015.

Valente, M.A.; Oliveira-Júnior, R.C.; Rodrigues, T.E.; Santos, P.L.; Silva, J.M.L.; Cardoso Júnior, E.Q. 1998. Solos da Ilha de Santana, Município de Santana, Estado do Amapá. Embrapa CPATU, Belém, 34p.

Vega-Rúa, A.; Zouache, K.; Girod, R.; Failloux, A.B.; Lourenço-deOliveira, R. 2014. High vector competence of Aedes aegypti and Aedes albopictus from ten American countries as a crucial factor of the spread of Chikungunya. Journal of Virology, 88: 6294-6306.

WRBU. 2018. Walter Reed Biosystematics Unit. Systematic Catalog of Culicidae (http://www.mosquitocatalog.org/). Accessed on 01 Oct 2018.

RECEIVED: $17 / 07 / 2018$

ACCEPTED: $15 / 10 / 2018$

ASSOCIATE EDITOR: Claudia Keller 